\title{
PELATIHAN PENILAIAN KETERAMPILAN PROSES SAINS BAGI GURU SMA MAPEL KIMIA DI KABUPATEN BANYUWANGI
}

\author{
Oleh: \\ Muchlis ${ }^{1}$, Rudiana Agustini², Harun Nasrudin² \\ 1,2,3 Jurusan Kimia FMIPA Unesa \\ ${ }^{1}$ muchlis_kimia@yahoo.co.id
}

\begin{abstract}
Abstrak
Tujuan PKM ini adalah (1) mendeskripsikan pemahaman materi penilaian keterampilan proses sains peserta pelatihan, (2) mendeskripsikan kemampuan peserta pelatihan dalam menyusun instrumen penilaian keterampilan proses sains, (3) mendeskripsikan kemampuan peserta pelatihan dalam menerapkan penilaian keterampilan proses sains dalam pembelajaran di kelas, dan (4) mendeskripsikan respon peserta pelatihan terhadap kegiatan pelatihan penilaian keterampilan proses sains ini. Kegiatan pelatihan ini terdiri atas beberapa langkah: (1) Pembelajaran selama beberapa jam oleh tim PKM terhadap peserta pelatihan yaitu guru-guru MGMP Mapel Kimia SMA Kabupaten Banyuwangi dalam rangka penyegaran materi penilaian keterampilan proses sains, (2) Tim PKM menilai instrumen penilaian keterampilan proses sains yang dikembangkan peserta pelatihan, (3) Tim PKM melaksanakan kegiatan pemantauan selama guru melakukan penilaian keterampilan proses sains untuk mendapatkan data kemampuan guru menerapkan penilaian keterampilan proses sains dalam pembelajaran di kelas, dan (4) Tim PKM memberikan angket kepada peserta untuk mendapatkan data respon peserta terhadap pelaksanaan pelatihan penilaian keterampilan proses sains. Instrumen dalam kegiatan pelatihan ini meliputi (1) Tes tulis untuk mengukur pemahaman peserta tentang penilaian keterampilan proses sains, (2) IPKG 1 untuk mengukur kemampuan guru menyusun RPP berbasis penilaian keterampilan proses sains, (3) IPKG 2 untuk mengukur kemampuan guru menerapkan penilaian keterampilan proses sains dalam pembelajaran di kelas, dan (4) Angket untuk mengukur respon peserta terhadap pelaksanaan pelatihan penilaian keterampilan proses sains. Berdasarkan hasil analisis dapat disimpulkan bahwa "hasil pelatihan penilaian keterampilan proses sains di MGMP Mapel Kimia SMA Kabupaten Banyuwangi" adalah baik, dengan didukung oleh fakta bahwa (1) Pemahaman materi penilaian keterampilan proses sains peserta pelatihan dalam kategori baik $(66,7 \%$ peserta) dan kategori sangat baik $(33,3 \%)$, (2) Kemampuan peserta pelatihan dalam menyusun RPP berbasis penilaian keterampilan proses sains dalam kategori sangat baik (rata-rata penilaian 88,1 ) untuk kelompok pertama dan sangat baik (rata-rata penilaian 87,6) pula untuk kelompok kedua, (3) Kemampuan peserta pelatihan dalam menerapkan penilaian keterampilan proses sains dalam pembelajaran di kelas dalam kategori sangat baik (rata-rata penilaian 91,2) untuk kelompok pertama dan sangat baik (rata-rata penilaian 89,3) pula untuk kelompok kedua, dan (4) Respon peserta pelatihan terhadap kegiatan pelatihan penilaian keterampilan proses sains menunjukkan respon positif.
\end{abstract}

Kata Kunci: PKM, penilaian KPS, mapel kimia

\section{Abstract}

The aims of this community service to (1) to describe the understanding of material assessment science process skills of participants, (2) describe the ability of participants to prepare an assessment instrument of science process skills, (3) describe the ability of trainees in applying ratings science process skills in the classroom, and (4) describe the response of participants to the training activities of this science process skills assessment. This training consists of several steps: (1) Learning for several hours by a team of PKM to trainees, are MGMP of Chemistry Teachers Banyuwangis Senior High School in order to refresh the material assessment science process skills, (2) PKM team assess assessment instruments science process skills developed trainees, (3) PKM team carry out monitoring activities for teachers to assess science process skills to get the data the ability of teachers to apply ratings science process skills in the classroom, and (4) PKM team provides a questionnaire to the participants to get the response data of participants the implementation of the science process skills assessment training. Instruments in these training activities include (1) Written test to measure the participants' understanding of the ratings science process skills, (2) IPKG 1 to measure the ability of teachers write lesson plans based on ratings science process skills, (3) IPKG 2 to measure a teacher's ability to apply skills assessment the process of science in the classroom, and (4) questionnaire to measure participants' responses to the implementation of the science process skills assessment training. Based on the analysis it can be concluded that the "results of science process skills assessment training in High School Chemistry MGMPs Mapel Banyuwangi" is good, supported by the fact that (1) Understanding materials science process skills assessment of trainees in either category (66.7\% of participants) and the very good category (33.3\%), (2) the ability of participants in 
preparing the RPP-based assessment of science process skills in the excellent category (average rating of 88.1) for the first group and very good (average 87 votes ,6) Similarly for the second group, (3) the ability of trainees in applying the science process skills assessment in the classroom in the excellent category (average rating of 91.2) for the first group and very good (an average of 89 votes, 3) Similarly to the second group, and (4) the response of participants to the training activities of science process skills assessment showed a positive response.

Keywords: Community service, science process skills, Chemistry

\section{PENDAHULUAN}

Universitas Negeri Surabaya (Unesa) menyelenggarakan layanan pendidikan di semua tingkat pendidikan, yaitu pendidikan tinggi, sekolah menengah atas, sekolah menengah pertama, sekolah dasar, dan taman kanak-kanak sebagai wujud pelayanan pendidikan. Salah satu wujud nyata pelayanan pendidikan ini adalah kerjasama antara Jurusan Kimia FMIPA Unesa dengan guru-guru SMA yang tergabung dalam MGMP Kimia Kabupaten Banyuwangi. Ada sekitar 49 SMA negeri dan swasta, dan 36 SMK negeri dan swasta di Kabupaten Banyuwangi. SMA dan SMK di Kabupaten Banyuwangi sebagian menerapkan Kurikulum 2013 dan sebagian lagi menerapkan KBK.

Komponen terpenting implementasi kurikulum adalah pelaksanaan proses pembelajaran yang diselenggarakan di dalam dan/atau luar kelas untuk membantu peserta didik mencapai kompetensi sikap, pengetahuan dan keterampilan. Peraturan Menteri Pendidikan dan Kebudayaan nomor 22 tahun 2016 tentang Standar Proses menyatakan bahwa proses pembelajaran menggunakan pendekatan atau metode pembelajaran yang sesuai dengan karakteristik peserta didik dan mata pelajaran. Di antara pendekatan dan metode yang dianjurkan dalam Standar Proses tersebut adalah pendekatan saintifik, inkuiri, pembelajaran berbasis masalah dan pembelajaran berbasis projek pada semua mata pelajaran. Pendekatan/metode lainnya yang dapat diimplementasikan antara lain pembelajaran kontekstual dan pembelajaran kooperatif (Kemendikbud A, 2016).

Sesuai dengan Peraturan Menteri Pendidikan dan Kebudayaan No. 23 Tahun 2016 tentang Standar Penilaian Pendidikan, penilaian pencapaian kompetensi pada jenjang pendidikan dasar dan menengah dilaksanakan oleh pendidik, satuan pendidikan, pemerintah dan/atau lembaga mandiri. Penilaian pencapaian kompetensi oleh pendidik dilakukan untuk memantau proses, kemajuan, dan perkembangan pencapaian kompetensi peserta didik sesuai dengan potensi yang dimiliki dan kemampuan yang diharapkan secara berkesinambungan. Penilaian juga dapat memberikan umpan balik kepada pendidik agar dapat menyempurnakan perencanaan dan proses pembelajaran. (Kemendikbud B, 2016).

Mata pelajaran kimia adalah salah satu dari mata pelajaran yang juga harus dilakukan penilaian. Namun yang sering dilakukan adalah penilaian produk dan sikap ilmiah. Sementara mata pelajaran kimia merupakan bagian dari sains, dan hakikat sains mencakup tiga hal yaitu 1) produk ilmiah, 2) proses ilmiah dan 3) sikap ilmiah (Mariana dan Praginda, 2009). Produk ilmiah dapat berupa konsep, prinsip, hukum dan teori. Proses ilmiah mencakup perumusan masalah, perumusan hipotesis, pengumpulan data, menganalisis data dan menyimpulkan. Keterampilan melaksanakan proses sains ini biasa dikenal dengan istilah keterampilan proses sains. Sikap ilmiah meliputi keteguhan hati, ketekunan, keingintahuan dan menyingkap rahasia alam. Dengan demikian penilaian mata pelajaran kimia seharusnya tidak hanya produk dan sikap ilmiah, tetapi juga keterampilan proses sainsnya.

Tujuan PKM ini adalah (1) mendeskripsikan pemahaman materi penilaian keterampilan proses sains peserta pelatihan, (2) mendeskripsikan kemampuan peserta pelatihan dalam menyusun instrumen penilaian keterampilan proses sains, (3) mendeskripsikan kemampuan peserta pelatihan dalam menerapkan penilaian keterampilan proses sains dalam pembelajaran di kelas, dan (4) mendeskripsikan respon peserta pelatihan terhadap kegiatan pelatihan penilaian keterampilan proses sains ini.

\section{METODE PELAKSANAAN}

Kegiatan pelatihan ini terdiri atas beberapa langkah: (1) Pembelajaran selama beberapa jam oleh tim PKM peserta pelatihan yaitu 
guru-guru MGMP Mapel Kimia SMA Kabupaten Banyuwangi dalam rangka penyegaran materi penilaian keterampilan proses sains, (2) Tim PKM menilai instrumen penilaian keterampilan proses sains yang dikembangkan peserta pelatihan, (3) Tim PKM melaksanakan kegiatan pemantauan selama guru melakukan penilaian keterampilan proses sains untuk mendapatkan data kemampuan guru menerapkan penilaian keterampilan proses sains dalam pembelajaran di kelas, dan (4) Tim PKM memberikan angket kepada peserta untuk mendapatkan data respon peserta terhadap pelaksanaan pelatihan penilaian keterampilan proses sains.

Instrumen dalam kegiatan pelatihan ini meliputi (1) Tes tulis untuk mengukur pemahaman peserta tentang penilaian keterampilan proses sains, (2) IPKG 1 untuk mengukur kemampuan guru menyusun RPP berbasis penilaian keterampilan proses sains, (3) IPKG 2 untuk mengukur kemampuan guru menerapkan penilaian keterampilan proses sains dalam pembelajaran di kelas, dan (4) Angket untuk mengukur respon peserta terhadap pelaksanaan pelatihan penilaian keterampilan proses sains.

Selanjutnya data dianalisis sebagai berikut: (1) data pemahaman peserta setelah pembelajaran dalam rangka penyegaran penilaian keterampilan proses sains dinyatakan sebagai berikut:

$$
\text { Nilai }=\frac{\text { Skor diperoleh }}{\text { Skor maksimum }} \times 100
$$

Pemahaman peserta dikelompokkan dalam kategori 'Baik' atau 'Sangat Baik' dan seterusnya sebagaimana tertera dalam Tabel 1; (2) data tentang kemampuan guru menyusun RPP berbasis penilaian keterampilan proses sains dinyatakan sebagai berikut:

$$
\text { Nilai }=\frac{\text { Skor diperoleh }}{\text { Skor maksimum }} \times 100
$$

Nilai yang diperoleh peserta dalam menyusun RPP berbasis penilaian keterampilan proses sains ditafsirkan menggunakan Tabel 1.
Tabel 1. Pemaknaan nilai pemahaman peserta pelatihan terhadap Peniaian KPS, kemampuan guru menyusun RPP berbasis Penilaian KPS dan kemampuan menerapkannya di kelas

\begin{tabular}{cc}
\hline Nilai & Kategori \\
\hline $0-20$ & Sangat Buruk \\
$21-40$ & Buruk \\
$41-60$ & Cukup \\
$61-80$ & Baik \\
$81-100$ & Sangat Baik \\
\hline \multicolumn{2}{c}{ (adaptasi dari Riduwan, 2011) }
\end{tabular}

(3) data tentang kemampuan guru menerapkan penilaian keterampilan proses sains dalam pembelajaran di kelas dianalisis secara deskriptif kuantitatif menggunakan rumus:

Nilai $=\frac{\text { Skor diperoleh }}{\text { Skor maksimum }} \times 100$

Nilai yang diperoleh peserta dalam menerapkan penilaian keterampilan proses sains di kelas ditafsirkan menggunakan Tabel 1; (4) data tentang respon peserta terhadap pelaksanaan pelatihan penilaian keterampilan proses sains dinyatakan dalam persentase dan pemaknaan besarnya persentase tiap item mengacu pada Tabel 2.

Tabel 2. Pemaknaan Persentase Respon Peserta Pelatihan

\begin{tabular}{cc}
\hline Persentase & Keterangan \\
\hline $0-20$ & Sangat Buruk \\
$21-40$ & Buruk \\
$41-60$ & Cukup \\
$61-80$ & Baik \\
$81-100$ & Sangat Baik \\
\hline \multicolumn{2}{r}{ (adaptasi dari Riduwan, 2011) }
\end{tabular}

\section{HASIL DAN PEMBAHASAN}

\section{Pemahaman Peserta Pelatihan tentang Materi Penilaian Keterampilan Proses Sains}

Peserta pelatihan penilaian keterampilan proses sains berjumlah 9 guru SMA mata pelajaran kimia. Secara singkat proses pelatihan diawali dengan pemaparan pengertian, contoh, dan pentingnya penilaian keterampilan proses sains. Kegiatan pelatihan dilanjutkan dengan kerja kelompok untuk menyusun instrumen penilaian 
keterampilan proses sains. Tim PKM mendampingi selama peserta bekerja dalam kelompok. Selanjutnya salah satu kelompok mempresentasikan hasil penyusunan instrumen berbasis penilaian keterampilan proses sains. Tanya jawab antar kelompok dan kelompok dengan tim PKM terus berlanjut hingga peserta memahami penilaian keterampilan proses sains.

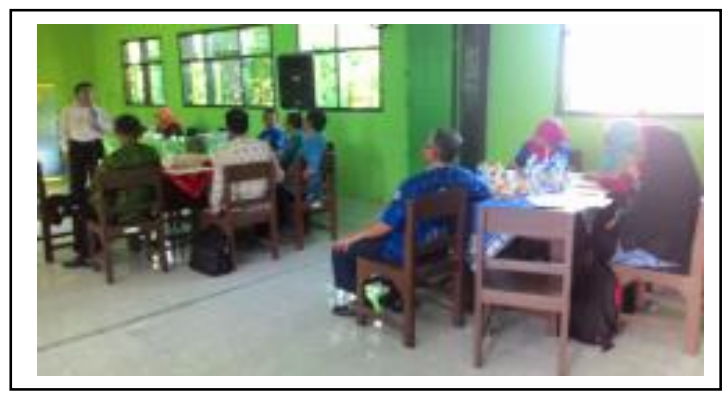

Gambar 1.Tim PKM menyampaikan pokokpokok penilaian keterampilan proses sains

Tes pemahaman tentang materi penilaian keterampilan proses sains dilaksanakan langsung setelah proses penyampaian materi penilaian keterampilan proses sains selesai. Hasil tes pemahaman dipaparkan dalam Tabel 3. Tes pemahaman penilaian keterampilan proses sains terdiri atas 4 item soal dengan item soal nomor 1 diberi skor 5 , item soal nomor 2 diberi skor 2 , item soal nomor 3 diberi skor 2 , dan item soal nomor 4 diberi skor 4 sehingga skor maksimum adalah 13.

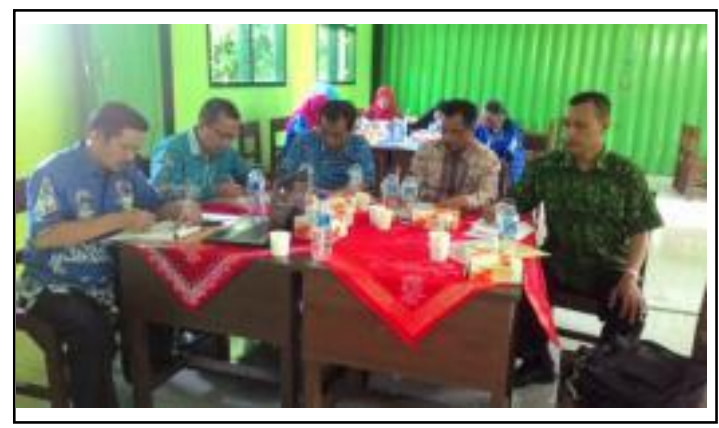

Gambar 2. Peserta sedang mengerjakan tes pemahaman penilaian keterampilan proses sains

Berdasarkan Tabel 3 terlihat bahwa 3 peserta $(33,3 \%)$ dalam kategori sangat baik dan 6 peserta $(66,7 \%)$ dalam kategori baik dalam penguasaan terhadap materi penilaian keterampilan proses sains. Namun demikian masih ada 2 peserta $(22,2 \%)$ yang mendapat nilai pada batas minimal kategori baik yaitu kode peserta 2 dan 6 . Kedua peserta ini mendapat nilai nol pada salah satu soal diantara empat soal yang harus dijawab.

Tabel 3. Nilai pemahaman peserta pelatihan tentang materi penilaian keterampilan proses sains

\begin{tabular}{|c|c|c|c|c|c|c|c|}
\hline \multirow[t]{2}{*}{$\begin{array}{l}\text { Kode } \\
\text { Peser- } \\
\text { ta }\end{array}$} & \multicolumn{4}{|c|}{$\begin{array}{l}\text { Skor diperoleh } \\
\text { untuk nomor } \\
\text { item soal }\end{array}$} & \multirow[t]{2}{*}{$\begin{array}{l}\text { skor } \\
\text { total }\end{array}$} & \multirow[t]{2}{*}{ Nilai } & \multirow[t]{2}{*}{ Kategori } \\
\hline & 1 & 2 & 3 & 4 & & & \\
\hline 1 & 5 & 1 & 2 & 4 & 12 & 92,0 & sangat baik \\
\hline 2 & 5 & 1 & 2 & 0 & 8 & 61,5 & baik \\
\hline 3 & 5 & 1 & 2 & 2 & 10 & 76,9 & baik \\
\hline 4 & 5 & 1 & 2 & 2 & 10 & 76,9 & baik \\
\hline 5 & 5 & 1 & 2 & 2 & 10 & 76,9 & baik \\
\hline 6 & 5 & 0 & 1 & 2 & 8 & 61,5 & baik \\
\hline 7 & 5 & 1 & 2 & 2 & 10 & 76,9 & baik \\
\hline 8 & 5 & 2 & 2 & 2 & 11 & 84,6 & sangat baik \\
\hline 9 & 5 & 2 & 2 & 2 & 11 & 84,6 & sangat baik \\
\hline
\end{tabular}

Item soal nomor 2 (Mengapa keterampilan proses sains harus diajarkan?) terlihat beberapa peserta pelatihan belum sepenuhnya menguasai 2 alasan yaitu alasan yuridis formal (Lampiran Permendikbud No. 22 tahun 2016) dan alasan teoritis. Mayoritas peserta hanya menjawab alasan teoritis sehingga hanya mendapatkan skor 1.Bahkan ada peserta dengan kode peserta 6 mendapat skor nol untuk nomor soal 2 karena salah menjawab. Demikian pula nomor soal 4 (Tuliskan masing-masing satu contoh asesmen untuk dua jenis keterampilan proses sains (KPS) yang Anda pilih!) ada peserta yang mendapat skor nol yaitu kode peserta 2 . Mayoritas peserta hanya mendapat skor 2 untuk item soal nomor 4 artinya mereka masih kurang mampu membuat instrumen penilaian keterampilan proses sains. Mereka hanya mampu membuat soalnya sementara rubriknya kurang paham.

\section{Kemampuan Peserta Pelatihan menyusun RPP berbasis Penilaian Keterampilan Proses Sains}

Peserta yang berjumlah 9 orang dalam penyusunan RPP berbasis penilaian keterampilan proses sains yang nantinya akan dipraktikkan di kelas yang sesungguhnya dibagi menjadi dua kelompok. Masing-masing kelompok terdapat seorang guru model dan lainnya bertindak sebagai penilai RPP dan pengamat ketika guru model mengajar di kelas.

Kemampuan peserta pelatihan dalam menyusun RPP berbasis penilaian 
keterampilan proses sains untuk kelompok pertama tertera dalam Tabel 2. Berdasarkan Tabel 4 menunjukkan bahwa kemampuan peserta pelatihan dalam menyusun RPP berbasis penilaian keterampilan proses sains memperoleh nilai 88,1 yang artinya sangat baik. Secara keseluruhan item RPP mendapat penilaian sangat baik. Namun kelogisan pengaturan waktu dalam RPP perlu mendapat perhatian karena hanya mendapat skor 3 dari masing-masing penilai RPP.

Tabel 4. Kemampuan menyusun RPP berbasis penilaian keterampilan proses sains untuk Kelompok Pertama

\begin{tabular}{|c|c|c|c|c|c|}
\hline \multirow{2}{*}{ NO. } & \multirow{2}{*}{ KOMPONEN RENCANA PEMBELAJARAN } & \multicolumn{3}{|c|}{ SKOR } & \multirow{2}{*}{ NILA } \\
\hline & & P1 & P1 & Jml & \\
\hline I & Perumusan indikator keberhasilan belajar & & & & \\
\hline 1. & Kejelasan rumusan & 4 & 4 & 8 & 87,5 \\
\hline 2. & Kejelasan penjenjangan indikator & 3 & 3 & 6 & \\
\hline 3. & Kesesuaian dengan kompetensi dasar & 4 & 4 & 8 & \\
\hline 4. & Pengakomodasian keterampilan proses sains & 3 & 3 & 6 & \\
\hline II & Pemilihan materi pembelajaran & & & & \\
\hline 1. & Kesesuaian dengan kompetensi yang akan dicapai & 4 & 4 & 8 & 83,3 \\
\hline 2. & Kesesuaian dengan karakteristik siswa & 3 & 3 & 6 & \\
\hline 3. & $\begin{array}{l}\text { Kesesuaian dengan tuntutan keterampilan proses } \\
\text { sains }\end{array}$ & 3 & 3 & 6 & \\
\hline III & Pengorganisasian materi pembelajaran & & & & \\
\hline 1. & Keruntutan dan sistematika materi & 4 & 4 & 8 & 75 \\
\hline 2. & Kesesuaian materi dengan alokasi waktu & 3 & 3 & 6 & \\
\hline IV & Pemilihan sumber belajar/media pembelajaran & & & & \\
\hline 1. & Kesesuaian dengan kompetensi yang ingin dicapai & 4 & 4 & 8 & 87,5 \\
\hline 2. & Kesesuaian dengan materi pembelajaran & 4 & 4 & 8 & \\
\hline 3. & Kesesuaian dengan metode pembelajaran & 3 & 3 & 6 & \\
\hline 4. & Kesesuaian dengan karakteristik siswa & 3 & 3 & 6 & \\
\hline $\mathbf{V}$ & Skenario pembelajaran keterampilan proses sains & & & & \\
\hline 1. & Kelengkapan pentahapan pembelajaran & 4 & 4 & 8 & 93,8 \\
\hline 2. & $\begin{array}{l}\text { Kejelasan langkah-langkah pembelajaran untuk setiap } \\
\text { tahap }\end{array}$ & 4 & 4 & 8 & \\
\hline 3. & $\begin{array}{l}\text { Kesesuaian alokasi waktu dengan tahapan } \\
\text { pembelajaran }\end{array}$ & 3 & 3 & 6 & \\
\hline 4. & $\begin{array}{l}\text { Kesesuaian jenis kegiatan pembelajaran dengan } \\
\text { kompetensi }\end{array}$ & 4 & 4 & 8 & \\
\hline VI & Asesmen & & & & \\
\hline 1. & Kesesuaian dengan kompetensi yang ingin dicapai & 4 & 4 & 8 & 93,8 \\
\hline 2. & $\begin{array}{l}\text { Kejelasan prosedur asesmen keterampilan proses } \\
\text { sains (awal, proses, akhir) }\end{array}$ & 4 & 4 & 8 & \\
\hline 3. & $\begin{array}{l}\text { Kelengkapan instrumen asesmen keterampilan proses } \\
\text { sains (soal, rubrik, kunci jawaban) }\end{array}$ & 4 & 4 & 8 & \\
\hline 4. & $\begin{array}{l}\text { Kualitas instrumen asesmen keterampilan proses } \\
\text { sains }\end{array}$ & 3 & 3 & 6 & \\
\hline VII & Penggunaan bahasa tulis & & & & \\
\hline 1. & Ketepatan ejaan & 4 & 4 & 8 & 95,8 \\
\hline 2. & Ketepatan pilihan kata & 4 & 4 & 8 & \\
\hline 3. & Kebakuan struktur kalimat & 3 & 4 & 7 & \\
\hline
\end{tabular}

Rata-rata nilai keseluruhan $\quad 88,1$

Keterangan: $\mathrm{P} 1,2=$ pengamat 1,2

$$
\mathrm{Jml}=\text { jumlah }
$$

Sementara itu, kemampuan peserta dalam membuat RPP berbasis penilaian keterampilan proses sains untuk kelompok kedua mendapat skor rata-rata 87,6 (dalam kategori sangat baik) sebagaimana tertera dalam Tabel 5. Secara keseluruhan komponen penilaian dalam kategori sangat baik, kecuali komponen pemilihan materi 
pembelajaran. Adapun komponen skenario pembalajaran berbasis keterampilan proses sains mendapat skor 90,6 (sangat baik). Demikian pula komponen kejelasan prosedur asesmen keterampilan proses sains (awal, proses, akhir) juga termasuk kategori sangat baik.

Tabel 5. Kemampuan menyusun RPP berbasis penilaian keterampilan proses sains untuk Kelompok Kedua

\begin{tabular}{|c|c|c|c|c|c|}
\hline \multirow{2}{*}{ NO. } & \multirow{2}{*}{ KOMPONEN RENCANA PEMBELAJARAN } & \multicolumn{3}{|c|}{ SKOR } & \multirow{2}{*}{ Nilai } \\
\hline & & P1 & P1 & Jml & \\
\hline $\mathbf{I}$ & Perumusan indikator keberhasilan belajar & & & & \\
\hline 1. & Kejelasan rumusan & 4 & 4 & 8 & 87,5 \\
\hline 2. & Kejelasan penjenjangan indikator & 3 & 3 & 6 & \\
\hline 3. & Kesesuaian dengan kompetensi dasar & 4 & 4 & 8 & \\
\hline 4. & Pengakomodasian keterampilan proses sains & 3 & 3 & 6 & \\
\hline II & Pemilihan materi pembelajaran & & & & \\
\hline 1. & Kesesuaian dengan kompetensi yang akan dicapai & 3 & 4 & 7 & 79,2 \\
\hline 2. & Kesesuaian dengan karakteristik siswa & 3 & 3 & 6 & \\
\hline 3. & Kesesuaian dengan tuntutan keterampilan proses sains & 3 & 3 & 6 & \\
\hline III & Pengorganisasian materi pembelajaran & & & & \\
\hline 1. & Keruntutan dan sistematika materi & 4 & 4 & 8 & 87,5 \\
\hline 2. & Kesesuaian materi dengan alokasi waktu & 3 & 3 & 6 & \\
\hline IV & Pemilihan sumber belajar/media pembelajaran & & & & \\
\hline 1. & Kesesuaian dengan kompetensi yang ingin dicapai & 4 & 4 & 8 & 87,5 \\
\hline 2. & Kesesuaian dengan materi pembelajaran & 4 & 4 & 8 & \\
\hline 3. & Kesesuaian dengan metode pembelajaran & 3 & 3 & 6 & \\
\hline 4. & Kesesuaian dengan karakteristik siswa & 3 & 3 & 6 & \\
\hline $\mathbf{V}$ & Skenario pembelajaran keterampilan proses sains & & & & \\
\hline 1. & Kelengkapan pentahapan pembelajaran & 4 & 4 & 8 & 90,6 \\
\hline 2. & $\begin{array}{l}\text { Kejelasan langkah-langkah pembelajaran untuk setiap } \\
\text { tahap }\end{array}$ & 3 & 4 & 7 & \\
\hline 3. & Kesesuaian alokasi waktu dengan tahapan pembelajaran & 3 & 3 & 6 & \\
\hline 4. & $\begin{array}{l}\text { Kesesuaian jenis kegiatan pembelajaran dengan } \\
\text { kompetensi }\end{array}$ & 4 & 4 & 8 & \\
\hline VI & Asesmen & & & & \\
\hline 1. & Kesesuaian dengan kompetensi yang ingin dicapai & 4 & 4 & 8 & 90,6 \\
\hline 2. & $\begin{array}{l}\text { Kejelasan prosedur asesmen keterampilan proses sains } \\
\text { (awal, proses, akhir) }\end{array}$ & 4 & 4 & 8 & \\
\hline 3. & $\begin{array}{l}\text { Kelengkapan instrumen asesmen keterampilan proses } \\
\text { sains (soal, rubrik, kunci jawaban) }\end{array}$ & 4 & 3 & 7 & \\
\hline 4. & Kualitas instrumen asesmen keterampilan proses sains & 3 & 3 & 6 & \\
\hline VII & Penggunaan bahasa tulis & & & & \\
\hline 1. & Ketepatan ejaan & 4 & 4 & 8 & 91,7 \\
\hline 2. & Ketepatan pilihan kata & 4 & 4 & 8 & \\
\hline 3. & Kebakuan struktur kalimat & 3 & 3 & 6 & \\
\hline
\end{tabular}

Keterangan: $\mathrm{P} 1,2=$ pengamat $1,2 \quad \mathrm{Jml}=$ jumlah

\section{Kemampuan Peserta Pelatihan Menerapkan RPP berbasis Penilaian Keterampilan Proses Sains}

Peserta dibagi dalam dua kelompok. Kemampuan peserta pelatihan dalam menerapkan RPP berbasis penilaian keterampilan proses sains diwakili oleh salah satu peserta dalam tiap kelompok. Bertindak sebagai pengamat dalam penerapan RPP berbasis penilaian keterampilan proses sains adalah 2 guru SMA mapel kimia dalam tiap kelompok. Kelompok pertama menerapkan penilaian keterampilan proses sains di SMAN 1 Glagah Banyuwangi. Secara singkat hasil pengamatan kemampuan peserta pelatihan dalam menerapkan RPP berbasis penilaian keterampilan proses sains untuk kelompok pertama tertulis dalam Tabel 6. 


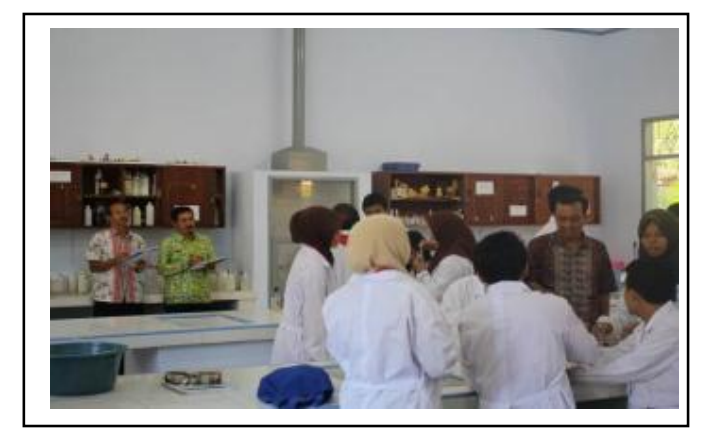

Gambar 3.Guru model dari kelompok pertama sedang menerapkan RPP berbasis penilaian keterampilan proses sains

Tabel 6. Kemampuan peserta pelatihan menerapkan RPP berbasis penilaian keterampilan proses sains untuk Kelompok Pertama

\begin{tabular}{|c|c|c|c|c|c|}
\hline \multirow{2}{*}{ NO } & \multirow{2}{*}{ ASPEK YANG DIAMATI } & \multicolumn{3}{|c|}{ SKOR } & \multirow{2}{*}{ Nilai } \\
\hline & & $\mathrm{P} 1$ & P2 & $\mathrm{Jml}$ & \\
\hline I & PRAPEMBELAJARAN & & & & \\
\hline 1. & $\begin{array}{l}\text { Memeriksa kesiapan ruang, alat pembelajaran, dan } \\
\text { media }\end{array}$ & 4 & 4 & 8 & 87,5 \\
\hline 2. & Memeriksa kesiapan siswa & 3 & 3 & 6 & \\
\hline II & MEMBUKA PEMBELAJARAN & & & & \\
\hline 1. & Melakukan kegiatan apersepsi & 3 & 3 & 6 & 87,5 \\
\hline 2. & $\begin{array}{l}\text { Menyampaikan kompetensi yang akan dicapai dan } \\
\text { rencana kegiatannya }\end{array}$ & 4 & 4 & 8 & \\
\hline III & KEGIATAN INTI PEMBELAJARAN & & & & \\
\hline A. & Penguasaan materi pelajaran & & & & \\
\hline 1. & Menunjukkan penguasaan materi pembelajaran & 4 & 4 & 8 & 95,0 \\
\hline 2. & Mengaitkan materi dengan pengetahuan lain yang relevan & 4 & 4 & 8 & \\
\hline 3. & Menyampaikan materi sesuai dengan hierarki belajar & 4 & 4 & 8 & \\
\hline 4. & Mengaitkan materi dengan realitas kehidupan & 4 & 4 & 8 & \\
\hline 5. & $\begin{array}{l}\text { Mengintegrasikan prinsip-prinsip keterampilan proses } \\
\text { sains dalam pembelajaran }\end{array}$ & 3 & 3 & 6 & \\
\hline B. & Pendekatan/strategi pembelajaran & & & & \\
\hline 1. & $\begin{array}{l}\text { Melaksanakan pembelajaran sesuai dengan kompetensi } \\
\text { yang akan dicapai }\end{array}$ & 3 & 3 & 6 & 87,5 \\
\hline 2. & $\begin{array}{l}\text { Melaksanakan pembelajaran sesuai dengan tingkat } \\
\text { perkembangan dan kebutuhan siswa }\end{array}$ & 3 & 3 & 6 & \\
\hline 3. & Melaksanakan pembelajaran secara runtut & 4 & 4 & 8 & \\
\hline 4. & Melaksanakan pembelajaran yang terkoordinasi & 4 & 4 & 8 & \\
\hline 5. & Melaksanakan pembelajaran yang bersifat kontekstual & 4 & 4 & 8 & \\
\hline 6. & $\begin{array}{l}\text { Melaksanakan pembelajaran yang memungkinkan } \\
\text { terlatihkannya keterampilan proses sains }\end{array}$ & 3 & 3 & 6 & \\
\hline 7. & $\begin{array}{l}\text { Melaksanakan pembelajaran sesuai dengan waktu yang } \\
\text { telah dialokasikan }\end{array}$ & 4 & 3 & 7 & \\
\hline C. & Pemanfaatan media pembelajaran/sumber belajar & & & & \\
\hline 1. & Menunjukkan keterampilan dalam penggunaan media & 4 & 4 & 8 & 92,5 \\
\hline 2. & Menghasilkan pesan yang menarik & 4 & 3 & 7 & \\
\hline 3. & Menggunakan media secara efektif dan efisien & 3 & 3 & 6 & \\
\hline 4. & Melibatkan siswa dalam pemanfaatan media & 4 & 4 & 8 & \\
\hline 5. & Melibatkan siswa dalam pemanfaatan sumber belajar & 4 & 4 & 8 & \\
\hline
\end{tabular}




\begin{tabular}{|c|c|c|c|c|c|}
\hline \multirow{2}{*}{ NO } & \multirow{2}{*}{ ASPEK YANG DIAMATI } & \multicolumn{3}{|c|}{ SKOR } & \multirow{2}{*}{ Nilai } \\
\hline & & P1 & P2 & $\mathrm{Jml}$ & \\
\hline D. & $\begin{array}{l}\text { Pembelajaran yang memicu dan memelihara } \\
\text { keterlibatan siswa }\end{array}$ & & & & \\
\hline 1. & Menumbuhkan partisipasi aktif siswa dalam pembelajaran & 3 & 3 & 6 & 87,5 \\
\hline 2. & Merespon positif partisipasi siswa & 4 & 4 & 8 & \\
\hline 3. & $\begin{array}{l}\text { Memfasilitasi terjadinya interaksi guru, siswa, dan sumber } \\
\text { belajar }\end{array}$ & 4 & 4 & 8 & \\
\hline 4. & Menunjukkan sikap terbuka terhadap respons siswa & 4 & 4 & 8 & \\
\hline 5. & Menunjukkan hubungan antarpribadi yang kondusif & 3 & 3 & 6 & \\
\hline 6. & $\begin{array}{l}\text { Menumbuhkan keceriaan dan antusisme siswa dalam } \\
\text { belajar }\end{array}$ & 3 & 3 & 6 & \\
\hline E. & $\begin{array}{l}\text { Penilaian proses dan hasil belajar (keterampilan } \\
\text { proses sains) }\end{array}$ & & & & \\
\hline 1. & Melakukan penilaian awal & 4 & 4 & 8 & 91.6 \\
\hline 2. & Memantau kemajuan belajar & 3 & 3 & 6 & \\
\hline 3. & Melakukan penilaian akhir sesuai dengan kompetensi & 4 & 4 & 8 & \\
\hline F. & Penggunaan bahasa & & & & \\
\hline 1. & Menggunakan bahasa lisan secara jelas dan lancar & 4 & 4 & 8 & 91,6 \\
\hline 2. & Menggunakan bahasa tulis yang baik dan benar & 4 & 4 & 8 & \\
\hline 3. & Menyampaikan pesan dengan gaya yang sesuai & 3 & 3 & 6 & \\
\hline IV & PENUTUP & & & & \\
\hline A. & Refleksi dan ranqkuman pembelajaran & & & & \\
\hline 1. & $\begin{array}{l}\text { Melakukan refleksi pembelajaran dengan melibatkan } \\
\text { siswa }\end{array}$ & 4 & 4 & 8 & 100 \\
\hline 2. & Menyusun rangkuman dengan melibatkan siswa & 4 & 4 & 8 & \\
\hline 3. & Memberikan tugas lanjutan & 4 & 4 & 8 & \\
\hline
\end{tabular}

\begin{abstract}
Berdasarkan Tabel 6 tampak bahwa kemampuan peserta pelatihan dalam menerapkan RPP berbasis penilaian keterampilan proses sains mendapat nilai 91,2 (sangat baik). Secara khusus komponen penilaian proses dan hasil belajar (keterampilan proses sains) mendapat skor 91,6 (sangat baik) yang berarti guru dari kelompok pertama telah melakukan penilaian keterampilan proses sains dengan sangat baik.

Sementara itu, kelompok kedua menerapkan penilaian keterampilan proses sains di SMAN 1 Banyuwangi. Rekapitulasi kemampuan guru dalam menerapkan penilaian keterampilan proses sains di kelas yang sesungguhnya tertera dalam Tabel 7.

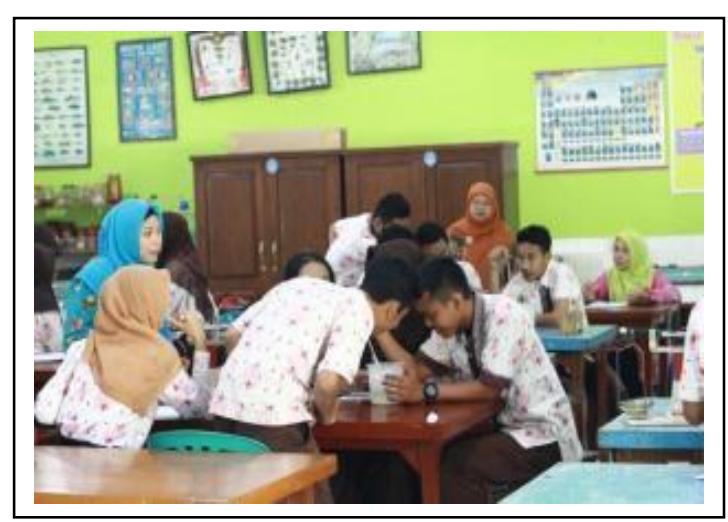

Gambar 4. Guru model dari kelompok kedua sedang menerapkan RPP berbasis penilaian keterampilan proses sains
\end{abstract}

Tabel 7. Kemampuan peserta pelatihan menerapkan RPP berbasis penilaian keterampilan proses sains untuk Kelompok Kedua

\begin{tabular}{|c|c|c|c|c|c|}
\hline \multirow{2}{*}{ NO } & \multirow{2}{*}{ ASPEK YANG DIAMATI } & \multicolumn{3}{|c|}{ SKOR } & \multirow{2}{*}{ Nilai } \\
\hline & & $\mathrm{P} 1$ & $\mathrm{P} 2$ & $\mathrm{Jml}$ & \\
\hline I & PRAPEMBELAJARAN & & & & \\
\hline 1. & $\begin{array}{l}\text { Memeriksa kesiapan ruang, alat pembelajaran, dan } \\
\text { media }\end{array}$ & 4 & 3 & 7 & 81,3 \\
\hline
\end{tabular}




\begin{tabular}{|c|c|c|c|c|c|}
\hline \multirow{2}{*}{ NO } & \multirow{2}{*}{ ASPEK YANG DIAMATI } & \multicolumn{3}{|c|}{ SKOR } & \multirow{2}{*}{ Nila } \\
\hline & & P1 & P2 & $\mathrm{Jml}$ & \\
\hline 2. & Memeriksa kesiapan siswa & 3 & 3 & 6 & \\
\hline II & MEMBUKA PEMBELAJARAN & & & & \\
\hline 1. & Melakukan kegiatan apersepsi & 3 & 3 & 6 & 87,5 \\
\hline 2. & $\begin{array}{l}\text { Menyampaikan kompetensi yang akan dicapai dan } \\
\text { rencana kegiatannya }\end{array}$ & 4 & 4 & 8 & \\
\hline IIII & KEGIATAN INTI PEMBELAJARAN & & & & \\
\hline A. & Penguasaan materi pelajaran & & & & \\
\hline 1. & Menunjukkan penguasaan materi pembelajaran & 4 & 4 & 8 & 95,0 \\
\hline 2. & Mengaitkan materi dengan pengetahuan lain yang relevan & 4 & 4 & 8 & \\
\hline 3. & Menyampaikan materi sesuai dengan hierarki belajar & 4 & 4 & 8 & \\
\hline 4. & Mengaitkan materi dengan realitas kehidupan & 4 & 4 & 8 & \\
\hline 5. & $\begin{array}{l}\text { Mengintegrasikan prinsip-prinsip keterampilan proses } \\
\text { sains dalam pembelajaran }\end{array}$ & 3 & 3 & 6 & \\
\hline B. & Pendekatan/strategi pembelajaran & & & & \\
\hline 1. & $\begin{array}{l}\text { Melaksanakan pembelajaran sesuai dengan kompetensi } \\
\text { yang akan dicapai }\end{array}$ & 3 & 3 & 6 & 87,5 \\
\hline 2. & $\begin{array}{l}\text { Melaksanakan pembelajaran sesuai dengan tingkat } \\
\text { perkembangan dan kebutuhan siswa }\end{array}$ & 3 & 3 & 6 & \\
\hline 3. & Melaksanakan pembelajaran secara runtut & 4 & 3 & 7 & \\
\hline 4. & Melaksanakan pembelajaran yang terkoordinasi & 4 & 4 & 8 & \\
\hline 5. & Melaksanakan pembelajaran yang bersifat kontekstual & 4 & 3 & 7 & \\
\hline 6. & $\begin{array}{l}\text { Melaksanakan pembelajaran yang memungkinkan } \\
\text { terlatihkannya keterampilan proses sains }\end{array}$ & 3 & 4 & 7 & \\
\hline 7. & $\begin{array}{l}\text { Melaksanakan pembelajaran sesuai dengan waktu yang } \\
\text { telah dialokasikan }\end{array}$ & 4 & 3 & 7 & \\
\hline C. & Pemanfaatan media pembelajaran/sumber belajar & & & & \\
\hline 1. & Menunjukkan keterampilan dalam penggunaan media & 4 & 4 & 8 & 92,5 \\
\hline 2. & Menghasilkan pesan yang menarik & 4 & 3 & 7 & \\
\hline 3. & Menggunakan media secara efektif dan efisien & 3 & 3 & 6 & \\
\hline 4. & Melibatkan siswa dalam pemanfaatan media & 4 & 4 & 8 & \\
\hline 5. & Melibatkan siswa dalam pemanfaatan sumber belajar & 4 & 4 & 8 & \\
\hline D. & $\begin{array}{l}\text { Pembelajaran yang memicu dan memelihara } \\
\text { keterlibatan siswa }\end{array}$ & & & & \\
\hline 1. & Menumbuhkan partisipasi aktif siswa dalam pembelajaran & 3 & 3 & 6 & 87,5 \\
\hline 2. & Merespon positif partisipasi siswa & 4 & 4 & 8 & \\
\hline 3. & $\begin{array}{l}\text { Memfasilitasi terjadinya interaksi guru, siswa, dan sumber } \\
\text { belajar }\end{array}$ & 4 & 4 & 8 & \\
\hline 4. & Menunjukkan sikap terbuka terhadap respons siswa & 4 & 4 & 8 & \\
\hline 5. & Menunjukkan hubungan antarpribadi yang kondusif & 3 & 3 & 6 & \\
\hline 6. & $\begin{array}{l}\text { Menumbuhkan keceriaan dan antusisme siswa dalam } \\
\text { belajar }\end{array}$ & 3 & 3 & 6 & \\
\hline E. & $\begin{array}{l}\text { Penilaian proses dan hasil belajar (keterampilan proses } \\
\text { sains) }\end{array}$ & & & & \\
\hline 1. & Melakukan penilaian awal & 4 & 4 & 8 & 91,7 \\
\hline 2. & Memantau kemajuan belajar & 3 & 3 & 6 & \\
\hline 3. & Melakukan penilaian akhir sesuai dengan kompetensi & 4 & 4 & 8 & \\
\hline F. & Penggunaan bahasa & & & & \\
\hline 1. & Menggunakan bahasa lisan secara jelas dan lancar & 4 & 3 & 7 & 87,5 \\
\hline 2. & Menggunakan bahasa tulis yang baik dan benar & 4 & 4 & 8 & \\
\hline 3. & Menyampaikan pesan dengan gaya yang sesuai & 3 & 3 & 6 & \\
\hline $\begin{array}{l}\text { IV } \\
\text { A. }\end{array}$ & $\begin{array}{l}\text { PENUTUP } \\
\text { Refleksi dan rangkuman pembelajaran }\end{array}$ & & & & \\
\hline 1. & $\begin{array}{l}\text { Melakukan refleksi pembelajaran dengan melibatkan } \\
\text { siswa }\end{array}$ & 4 & 4 & 8 & 95,8 \\
\hline
\end{tabular}




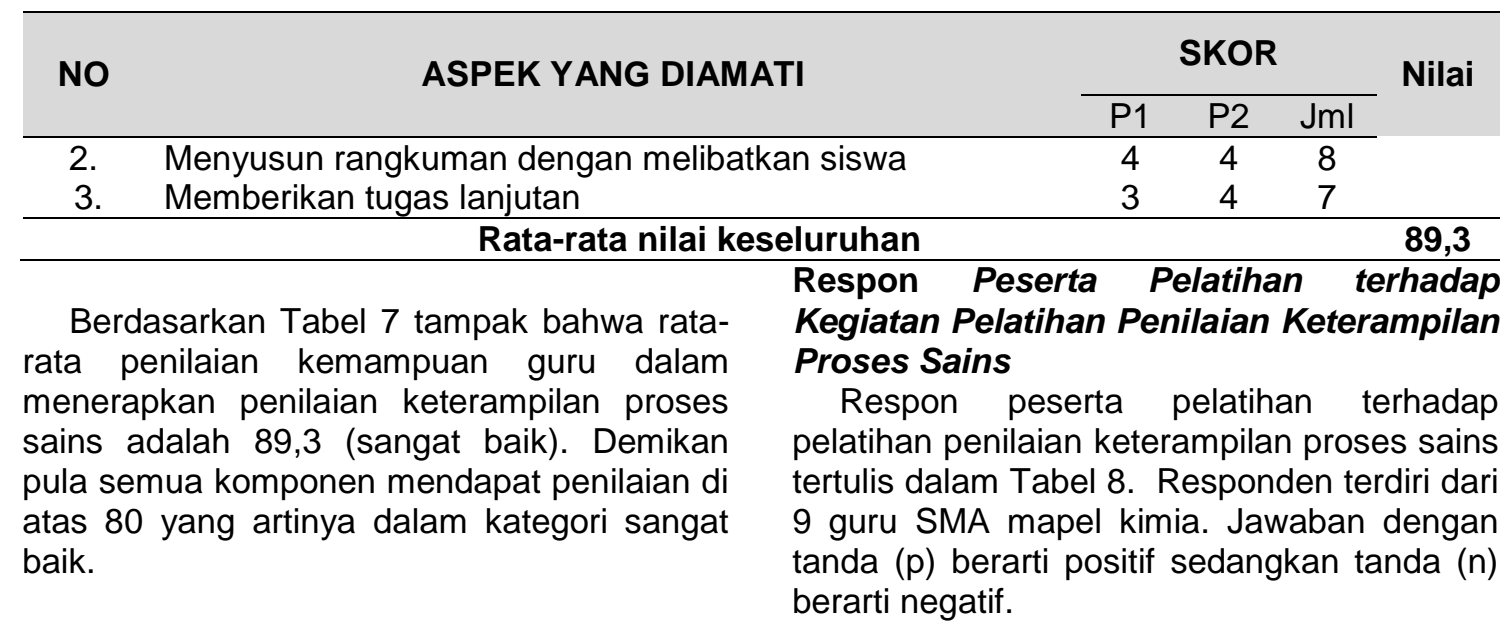

Tabel 8. Respon peserta pelatihan terhadap pelatihan penilaian keterampilan proses sains

\begin{tabular}{|c|c|c|c|}
\hline Item respon & Jawaban & Jumlah & $\begin{array}{c}\text { Persentase } \\
(\%)\end{array}$ \\
\hline Menurut Anda materi pelatihan ini & $\begin{array}{l}\text { Menarik }(p) \\
\text { kurang menarik }(p) \\
\text { tidak menarik }(n)\end{array}$ & $\begin{array}{l}9 \\
0 \\
0\end{array}$ & 100 \\
\hline $\begin{array}{lcr}\text { Kompetensi } & \text { narasumber } & \text { terhadap } \\
\text { materi } & \text { yang } & \text { menjadi } \\
\text { tanggungjawabnya } & \end{array}$ & $\begin{array}{l}\text { Memadai }(p) \\
\text { cukup memadai }(p) \\
\text { kurang memadai }(n)\end{array}$ & $\begin{array}{l}7 \\
2 \\
0\end{array}$ & $\begin{array}{l}77,8 \\
22,2\end{array}$ \\
\hline $\begin{array}{l}\text { Penyampaian materi pelatihan oleh } \\
\text { narasumber }\end{array}$ & $\begin{array}{l}\text { efektif dan menarik }(p) \\
\text { kurang efektif dan menarik }(n) \\
\text { tidak efektif dan menarik }(n)\end{array}$ & $\begin{array}{l}8 \\
1 \\
0\end{array}$ & $\begin{array}{l}88,9 \\
11,1\end{array}$ \\
\hline $\begin{array}{l}\text { Penilaian keterampilan proses sains } \\
\text { dapat diterapkan pada semua materi } \\
\text { pokok mapel kimia }\end{array}$ & $\begin{array}{l}\text { Ya }(p) \\
\text { Beberapa }(p) \\
\text { tidak dapat }(n)\end{array}$ & $\begin{array}{l}6 \\
3 \\
0\end{array}$ & $\begin{array}{l}66,7 \\
33,3\end{array}$ \\
\hline $\begin{array}{l}\text { Sulit menerapkan penilaian } \\
\text { keterampilan proses sains pada } \\
\text { kegiatan belajar mengajar }\end{array}$ & $\begin{array}{l}\text { Mudah }(p) \\
\text { Sedang }(p) \\
\text { Sulit }(n)\end{array}$ & $\begin{array}{l}4 \\
5 \\
0\end{array}$ & $\begin{array}{l}44,4 \\
55,6\end{array}$ \\
\hline $\begin{array}{l}\text { Penilaian keterampilan proses sains } \\
\text { bermanfaat pada tugas mengajar } \\
\text { guru dan sesuai dengan kurikulum } \\
\text { sekolah }\end{array}$ & $\begin{array}{l}\text { Ya }(p) \\
\text { kurang bermanfaat }(n) \\
\text { tidak bermanfaat }(n)\end{array}$ & $\begin{array}{l}9 \\
0 \\
0\end{array}$ & 100 \\
\hline $\begin{array}{l}\text { Bagaimana keefektifan penilaian } \\
\text { keterampilan proses sains terhadap } \\
\text { keterampilan berpikir, motorik dan } \\
\text { afektif siswa }\end{array}$ & $\begin{array}{l}\text { Efektif }(p) \\
\text { kurang efektif }(n) \\
\text { tidak efektif }(n)\end{array}$ & $\begin{array}{l}8 \\
1 \\
0\end{array}$ & $\begin{array}{l}88,9 \\
11,1\end{array}$ \\
\hline $\begin{array}{l}\text { Apakah penilaian keterampilan } \\
\text { proses sains membantu siswa untuk } \\
\text { memahami, mempersiapkan dan } \\
\text { melatihkan pemecahan masalah di } \\
\text { dunia nyata melalui kegiatan belajar } \\
\text { di kelas }\end{array}$ & $\begin{array}{l}\text { Ya }(p) \\
\text { cukup membantu }(p) \\
\text { tidak membantu }(n)\end{array}$ & $\begin{array}{l}7 \\
2 \\
0\end{array}$ & $\begin{array}{l}77,8 \\
22,2\end{array}$ \\
\hline $\begin{array}{l}\text { Apakah penilaian keterampilan } \\
\text { proses sains berpengaruh terhadap } \\
\text { hasil belajar siswa? }\end{array}$ & $\begin{array}{l}\text { Ya }(p) \\
\text { cukup berpengaruh }(p) \\
\text { tidak berpengaruh }(n)\end{array}$ & $\begin{array}{l}7 \\
2 \\
0\end{array}$ & $\begin{array}{l}77,8 \\
22,2\end{array}$ \\
\hline $\begin{array}{l}\text { Menularkan hasil pelatihan ini } \\
\text { kepada rekan kerja saya }\end{array}$ & $\begin{array}{l}\text { Tidak }(n) \\
\text { Pasti }(p) \\
\text { Lihat kondisi }(p)\end{array}$ & $\begin{array}{l}1 \\
7 \\
1\end{array}$ & $\begin{array}{l}11,1 \\
77,8 \\
11,1\end{array}$ \\
\hline
\end{tabular}


Informasi dalam Tabel 8 menunjukkan bahwa jawaban-jawaban bernada positif mendapatkan persentase lebih dari $61 \%$. Hal ini menunjukkan bahwa peserta pelatihan penilaian keterampilan proses sains memberikan respon positif. Namun demikian ada beberapa item mendapat respon negatif sehingga perlu mendapat perhatian untuk kegiatan-kegiatan serupa di masa mendatang. Sebagai contoh satu peserta $(11,1 \%)$ memberi respon "kurang efektif dan menarik" terhadap item "penyampaian materi pelatihan oleh narasumber".

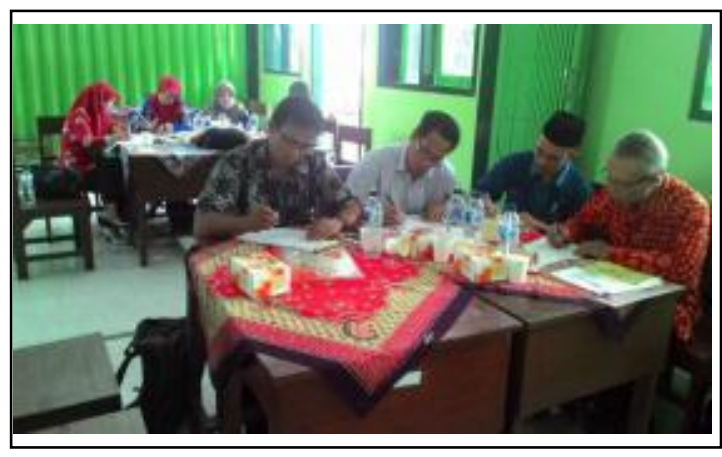

Gambar 5.Peserta sedang mengisi lembar respon dalam kegiatan penilaian keterampilan proses sains

\section{SIMPULAN DAN SARAN}

Berdasarkan uraian di atas dapat disimpulkan bahwa "hasil pelatihan penilaian keterampilan proses sains di MGMP Mapel Kimia SMA Kabupaten Banyuwangi" adalah baik, dengan didukung oleh fakta bahwa (1) pemahaman materi penilaian keterampilan proses sains peserta pelatihan dalam kategori baik $(66,7 \%$ peserta) dan kategori sangat baik $(33,3 \%)$; (2) kemampuan peserta pelatihan dalam menyusun RPP berbasis penilaian keterampilan proses sains dalam kategori sangat baik (rata-rata penilaian 88,1 ) untuk kelompok pertama dan sangat baik (rata-rata penilaian 87,6 ) pula untuk kelompok kedua; (3) kemampuan peserta pelatihan dalam menerapkan penilaian keterampilan proses sains dalam pembelajaran di kelas dalam kategori sangat baik (rata-rata penilaian 91,2) untuk kelompok pertama dan sangat baik (rata-rata penilaian 89,3 ) pula untuk kelompok kedua.; (4) Respon peserta pelatihan terhadap kegiatan pelatihan penilaian keterampilan proses sains menunjukkan respon positif.

Sebaiknya jenis dan jumlah contoh instrumen penilaian keterampilan proses sains diperbanyak dalam pelatihan serupa sehingga peserta lebih dapat memahami penilaian keterampilan proses sains.

\section{DAFTAR PUSTAKA}

Kemendikbud, 2014, Panduan Penguatan Proses Pembelajaran Sekolah Menengah Pertama.

Mariana, I Made Alit dan Praginda, Wandy. 2009. Hakikat IPA dan Pembelajaran IPA. Jakarta: PPPP TK Diknas.

Peraturan Menteri Pendidikan dan Kebudayaan Republik IndonesiaNomor 54 Tahun 2013 tentang Standar Kompetensi Lulusan Pendidikan Dasar dan Menengah

Peraturan Menteri Pendidikan dan Kebudayaan Republik Indonesia Nomor 64 Tahun 2013 tentang Standar Isi

Kemendikbud A. 2016. Peraturan Menteri Pendidikan dan Kebudayaan Republik IndonesiaNomor 22 Tahun 2016 tentang Standar Proses

Kemendikbud B. 2016. Peraturan Menteri Pendidikan dan Kebudayaan Republik IndonesiaNomor 23 Tahun 2016 tentang Standar Penilaian Pendidikan 